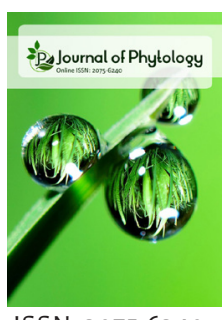

ISSN: $2075-6240$

\title{
A review on chemical constituents of essential oils of Aframomum genus
}

\author{
Hong Thien Van*, Tan Viet Pham, Hanh Thi Dieu Nguyen, Ngoc An Nguyen, \\ Duy H. Truong
}

Institute of Biotechnology and Food Technology, Industrial University of Ho Chi Minh City, No. 12 Nguyen Van Bao Street, Ward 4, Go Vap District, Ho Chi Minh City, Vietnam

Received: August 08, 2021 Revised: November 21, 2021 Accepted: November 22, 2021 Published: December 17, 2021

*Corresponding Author:

Hong Thien Van

E-mail:vanhongthien@iuh.edu.vn KEYWORDS: Essential oils, Aframomum, chemical components of various Aframomum species.

\section{ABSTRACT}

Aframomum K.Schum is a genus native to Africa belonging to Zingiberaceae. Members of genus Aframomum are the aromatic and perennial rhizomatous herbs. Many plant parts of Aframomum species contain essential oils, including fruits, seeds, leaves, stems, rhizomes, pods, husks, pericarps, limbos and leaf sheaths. The major constituents of Aframomum plants are mainly composed of sesquiterpene hydrocarbons, oxygenated monoterpenes, oxygenated sesquiterpenes and monoterpene hydrocarbons. The present work provides comprehensive information regarding the volatile components

\section{INTRODUCTION}

The Zingiberaceae family comprises over 1500 species belonging to 50 genera. Members on Zingiberaceae are rhizomatous herbs and widely found throughout tropical Africa, Asia, and tropical America (Kress et al., 2002). Several plant part of Zingiberaceae species such as seeds leaves, rhizomes and fruits have been used to treat heal bruises, sore throat, improve digestion, treat cough, and scars (Jantan et al., 2004). In addition, Zingiberaceae was considered as an important natural resources as it was raw material used in the production of medicines, spices, cosmetics and essential oil (Koga et al., 2016) (Zahara et al. 2018). In particular, many reports showed that their essential oil and major chemical components such as terpenes, alcohols, ketones, flavonoids and phytoestrogens have many biological activitives (Zahara et al., 2018).

Aframomum K.Schum, a genus with over 80 species belonging to the Zingiberaceae family, are widely distributed in West and Central Africa. They are the perennial and large plants reaching up 6 meters tall (Amadi et al., 2016). In the terms of traditional medicine, members of Aframomum have been commonly used by African as a remedy for antidiarrhoea, laxatives, anthelmintics, fever management, toothache, inflammatory conditions, stomach ache, postpartum haemorrhage and a tonic for sexual stimulation (Duke, 2002). In addition, diterpenoids, sesquiterpenoids, arylalkanoids and flavonoids are known as major phytochemicals of Aframomum species (Amadi et al., 2016). Several bioactivities of Aframomum plant, including antimicrobial, anticancer, antiplasmodial, antinociceptive, hepatoprotective and antiulcer activities have been reported by previous studies (El-Halawany et al., 2014).

Aframomum genus includes aromatic and perennial rhizomatous plants. The essential oils isolated from many plant parts of Aframomum species such as seeds, fruits, stems, rhizomes, leaves, pods, pericarps, husks, limbos and leaf sheaths possess some bioactive compounds. These components belong to different chemical groups such as oxygenated monoterpenes, monoterpene hydrocarbons, oxygenated sesquiterpenes, sesquiterpene hydrocarbons and non-terpenoid (Diomandé et al., 2012; Nguikwie et al., 2013; Huong et al., 2017). However, there is a limitation in the overall review of the phytochemicals of essential oils obtained from Aframomum plants. Therefore, the main focus of the present review gives an overview of the chemical profiles and bioactivities of the essential oils isolated from the Aframomum species.

\section{Volatile Compounds of Aframomum spp.}

Generally, the volatile compounds of Aframomum spp. were identified by Gas Chromatography Mass Spectrometry. The plant parts which studies focused on many materials such as fruits, seeds, leaves, stems, rhizomes, pods, husks, pericarps, limbos and leaf sheaths. The major volatile compounds of the Aframomum spp. isolated from various plant parts were summarized in Table 1. 
Table 1: Major components identifed from Aframomum essential oils

\begin{tabular}{|c|c|c|c|c|}
\hline Scientific name & Origin & Part & Major Components & References \\
\hline A. alboviolaceum & Contuboel, Guinea-Bissau & Rhizomes & $\begin{array}{l}\text { Intermedeol (24.1\%), carotol (8.3\%), spathulenol } \\
(5.8 \%)\end{array}$ & (Abreu \& Noronha, 1997) \\
\hline A. angustifolium & Madagascar & Seeds & $\begin{array}{l}\beta \text {-pinene }(24.8 \%), \beta \text {-caryophyllene }(17.8 \%) \text {, cis- } \\
\text { pinocarvyl acetate }(11.0 \%)\end{array}$ & $\begin{array}{l}\text { (Baser \& Kürkçüoglu, } \\
\text { 2001) }\end{array}$ \\
\hline A. biauriculatum & Zambia & Leaves & $\begin{array}{l}\beta \text {-pinene }(58.5 \%), \beta \text {-caryophyllene (14.2\%), } \alpha \text {-pinene } \\
(7.3 \%)\end{array}$ & (Chisowa et al., 1998) \\
\hline A. biaurlculatum & Zambia & Rhizomes & $\begin{array}{l}\beta \text {-pinene }(23.8 \%), 1,8 \text {-cineole }(22.5 \%), \alpha \text {-terpineol } \\
(5.0 \%)\end{array}$ & (Chisowa et al., 1998) \\
\hline A. citratum & Bafoussam, Cameroon & Seeds & Geraniol (96.8\%), linalool (1.3\%) & (Dongmo et al., 2019) \\
\hline A. citratum & Bafoussam, Cameroon & Seeds & Geraniol (97.6\%), geranyl acetate $(0.9 \%)$ & (Meffo et al., 2019) \\
\hline A. citratum & Yaounde, Cameroon & Leaves & $\begin{array}{l}\beta \text {-pinene }(62.0 \%), \alpha \text {-pinene }(11.0 \%), \beta \text {-caryophyllene } \\
(8.6 \%)\end{array}$ & (Amvam et al., 2002) \\
\hline A. citratum & Yaounde, Cameroon & Seeds & Geraniol (70.0\%), linalool (15.0\%), myrcene (1.5\%) & (Amvam et al., 2002) \\
\hline A. citratum & Kribi, Cameroon & Seeds & $\begin{array}{l}\text { Geraniol }(68.9 \%) \text { and linalool }(15.1 \%) \text {, } \\
\text { myrcene }(1.5 \%)\end{array}$ & (Chalchat et al., 1997) \\
\hline A. corrorima & Madagascar & Seeds & $\begin{array}{l}\text { 1,8-cineole }(32.6 \%),(E) \text {-nerolidol (11.2\%), } \alpha \text {-terpinyl } \\
\text { acetate }(9.2 \%)\end{array}$ & $\begin{array}{l}\text { (Baser \& Kürkçüoglu, } \\
\text { 2001) }\end{array}$ \\
\hline A. corrorima & southern Ethiopia & Leaves & $\begin{array}{l}\beta \text {-caryophyllene }(60.7 \%), \beta \text {-pinene (11.9\%), } \\
\text { caryophyllene oxide }(5.7 \%)\end{array}$ & (Eyob et al., 2008) \\
\hline A. corrorima & southern Ethiopia & Rhizomes & $\begin{array}{l}\gamma \text {-terpinene }(21.8 \%), \beta \text {-pinene }(17.6 \%), \beta \text {-caryophyllene } \\
(4.1 \%)\end{array}$ & (Eyob et al., 2008) \\
\hline A. corrorima & southern Ethiopia & Pods & $\begin{array}{l}\gamma \text {-terpinene }(27.1 \%), \beta \text {-pinene }(15.4 \%), \alpha \text {-phllandrene } \\
(8.5 \%)\end{array}$ & (Eyob et al., 2007) \\
\hline A. corrorima & southern Ethiopia & Seeds & 1,8-cineole $(39.3 \%)$, sabinene $(10.4 \%)$, geraniol $(6.8 \%)$ & (Eyob et al., 2007) \\
\hline A. corrorima & Merkato, Ethiopia & Seeds & 1,8-cineole $(44.3 \%)$, sabinene $(17.3 \%), \beta$-pinene $(7.2 \%)$ & (Hymete et al., 2006) \\
\hline A. corrorima & Merkato, Ethiopia & Husks & $\begin{array}{l}\text { (E)-nerolidol (17.2\%), } \beta \text {-caryophyllene }(9.7 \%) \text {, } \\
\text { caryophyllene oxide }(6.9 \%)\end{array}$ & (Hymete et al., 2006) \\
\hline A. corrorima & Jeddah, Saudi Arabia & Seeds & $\begin{array}{l}\text { 1,8-cineole }(51.8 \%) \text {, terpinen-4-ol (10.4\%), limonene } \\
(5.4 \%)\end{array}$ & (Noumi et al., 2018) \\
\hline A. dalzielii & Fontem, Cameroon & Seeds & (E)-nerolidol (91.2\%), 2-heptyl acetate (2.8\%) & (Nguikwie et al., 2013) \\
\hline A. dalzielii & Fontem, Cameroon & Pericarps & $\beta$-pinene $(43.3 \%)$, sabinene $(14.2 \%), \beta$-pinene $(7.8 \%)$ & (Nguikwie et al., 2013) \\
\hline A. dalzielii & Fontem, Cameroon & Leaves & $\begin{array}{l}\beta \text {-caryophyllene }(81.4 \%), \beta \text {-pinene }(3.9 \%) \text {, } \\
\text { caryophyllene oxide }(3.3 \%)\end{array}$ & (Nguikwie et al., 2013) \\
\hline A. dalzielii & Fontem, Cameroon & Rhizomes & $\beta$-pinene $(37.9 \%)$, sabinene $(22.9 \%), \alpha$-pinene $(7.8 \%)$ & (Nguikwie et al., 2013) \\
\hline A. daniellii & Bafoussam, Cameroon & Seeds & $\begin{array}{l}\text { 1,8-cineole }(48.8 \%), \alpha \text {-terpineol }(21.7 \%) \text {, geraniol } \\
(10.5 \%)\end{array}$ & (Dongmo et al., 2019) \\
\hline A. daniellii & Bafoussam, Cameroon & Seeds & $\begin{array}{l}\text { 1,8-cineole (51.5\%), } \alpha \text {-terpineol (12.5\%), } \beta \text {-pinene } \\
(8.5 \%)\end{array}$ & (Meffo et al., 2019) \\
\hline A. daniellii & Bafoussam, Cameroon & Seeds & $\begin{array}{l}\text { 1,8-cineole }(48.8 \%), \beta \text {-pinene }(11.2 \%), \alpha \text {-terpineol } \\
(10.8 \%)\end{array}$ & (Pavela et al., 2016) \\
\hline A. daniellii & Bafoussam, Cameroon & Pericarps & $\beta$-pinene (17.6\%), sabinene (11.7\%), linalool (10.2\%) & (Pavela et al., 2016) \\
\hline A. daniellii & Bafoussam, Cameroon & Leaves & $\begin{array}{l}\text { sabinene }(42.9 \%),(E) \text {-caryophyllene }(16.6 \%), \beta \text {-pinene } \\
(5.8 \%)\end{array}$ & (Pavela et al., 2016) \\
\hline A. daniellii & Bamougoum, Cameroon & Leaves & $\begin{array}{l}\text { Sabinene }(43.9 \%),(E) \text {-caryophyllene }(16.6 \%), \beta \text {-pinene } \\
(5.8 \%)\end{array}$ & (Kamte et al., 2017) \\
\hline A. daniellii & Balengou, Cameroon & Fruits & $\begin{array}{l}\text { 1,8-cineole }(48.9 \%) \text {, limonene }(12.8 \%), \beta \text {-pinene } \\
(12.7 \%)\end{array}$ & (Menut \& Lamaty, 1991) \\
\hline A. daniellii & Lagos State, Nigeria & Leaves & $\beta$-pinene $(25.1 \%)$, limonene $(13.8 \%), \alpha$-pinene $(10.9 \%)$ & (Lawal et al., 2017) \\
\hline A. daniellii & Lagos State, Nigeria & Seeds & $\begin{array}{l}\text { 1,8-cineole }(37.2 \%) \text {, linalool }(31.3 \%) \text {, terpinen- } 4-01 \\
(7.2 \%)\end{array}$ & (Lawal et al., 2017) \\
\hline A. daniellii & Rivers State, Nigeria & Seeds & $\begin{array}{l}\text { 1,8-cineole }(50.95 \%), \beta \text {-pinene (11.79\%) } \alpha \text {-terpineol } \\
(9.15 \%)\end{array}$ & (Emmanuel et al., 2020) \\
\hline A. daniellii & Akwa Ibom, Nigeria & Leaves & $\begin{array}{l}\beta \text {-pinene }(47.55 \%), \text { caryophyllene oxide (14.68\%), } \\
\beta \text {-caryophyllene }(9.73)\end{array}$ & (Essien et al., 2017) \\
\hline A. daniellii & Akwa Ibom, Nigeria & Stems & $\begin{array}{l}\beta \text {-pinene }(30.94 \%), \alpha \text {-phellandrene }(10.12 \%), \\
\beta \text {-terpinene }(8.98 \%)\end{array}$ & (Essien et al., 2017) \\
\hline A. daniellii & Akwa Ibom, Nigeria & Seeds & $\begin{array}{l}\text { 1,8-cineole }(53.44 \%), \alpha \text {-terpineol (12.23\%), } \beta \text {-pinene } \\
(9.15 \%)\end{array}$ & (Essien et al., 2017) \\
\hline A. daniellii & Akwa Ibom, Nigeria & Rhizomes & $\begin{array}{l}\beta \text {-pinene }(34.51 \%), \alpha \text {-phellandrene }(8.77 \%), \beta \text {-terpinene } \\
(9.81 \%)\end{array}$ & (Essien et al., 2017) \\
\hline A. daniellii & Akwa Ibom, Nigeria & Pods & $\begin{array}{l}\beta \text {-pinene }(34.55 \%), \alpha \text {-phellandrene }(12.26 \%), \\
\beta \text {-terpinene }(13.49 \%)\end{array}$ & (Essien et al., 2017) \\
\hline A. daniellii & Ibadan, Nigeria & Pods & $\begin{array}{l}\text { 1,8-cineole }(56.16 \%), \beta \text {-pinene }(14.77 \%), \alpha \text {-terpineol } \\
(11.46 \%)\end{array}$ & (Olosunde et al., 2015) \\
\hline A. daniellii & São Tomé and Príncipe & Fruits & $\begin{array}{l}\text { 1,8-cineole }(34.4 \%), \beta \text {-pinene }(15.2 \%), \alpha \text {-terpineol } \\
(12.1 \%)\end{array}$ & (Martins et al., 2001) \\
\hline
\end{tabular}


Table 1: (Continued)

\begin{tabular}{|c|c|c|c|c|}
\hline Scientific name & Origin & Part & Major Components & References \\
\hline A. daniellii & Akure, Nigeria & Seeds & $\begin{array}{l}\text { Eugenol }(51.14 \%), 1,8 \text {-cineole }(10.93 \%), \\
\beta \text {-caryophyllene }(5.11 \%)\end{array}$ & (Adefegha et al., 2017) \\
\hline A. elliotti & Ivory Coast & Leaves & $\begin{array}{l}\beta \text {-pinene }(44.3 \%), \beta \text {-caryophyllene }(26.2 \%), \alpha \text {-pinene } \\
(5.1 \%)\end{array}$ & (Diomandé et al., 2012) \\
\hline A. elliotti & Ivory Coast & Rhizomes & $\begin{array}{l}\text { Linalool }(45.3 \%), 1,8 \text {-cineole }(17.1 \%), \beta \text {-pinene } \\
(16.3 \%)\end{array}$ & (Diomandé et al., 2012) \\
\hline A. exscapum & Assouba, Ivory Coast & Leaves & $\begin{array}{l}\text { 1,8-cineole (52.9\%), (E)-Nerolidol (16.1\%), } \alpha \text {-Terpineol } \\
(6.3 \%)\end{array}$ & (Muriel et al., 2011) \\
\hline A. exscapum & Malamalasso, Ivory Coast & Leaves & $\begin{array}{l}\text { 1,8-cineole }(53.8 \%), \alpha \text {-Pinene }(7.9 \%), \text { Germacrene D } \\
(6.6 \%)\end{array}$ & (Muriel et al., 2011) \\
\hline A. exscapum & Nianda North, Ivory Coast & Leaves & $\begin{array}{l}\text { 1,8-cineole }(60 \%) \text {, Germacrene D }(6.9 \%), \alpha \text {-Terpineol } \\
(6.7 \%)\end{array}$ & (Muriel et al., 2011) \\
\hline A. exscapum & $\begin{array}{l}\text { Nianda Sounth, Ivory } \\
\text { Coast }\end{array}$ & Leaves & $\begin{array}{l}\text { 1,8-cineole }(61.0 \%) \text {, Germacrene D (6.9\%), } \beta \text {-Pinene } \\
(6.3 \%)\end{array}$ & (Muriel et al., 2011) \\
\hline A. exscapum & Nianda East, Ivory Coast & Leaves & 1,8-cineole, Germacrene D (7.3\%), $\beta$-Pinene $(6.4 \%)$ & (Muriel et al., 2011) \\
\hline A. geocarpum & Ivory Coast & Leaves & $\begin{array}{l}\beta \text {-caryophyllene (58.1\%), } \beta \text {-humulene (15.0\%), } \beta \text {-pinene } \\
(11.3 \%)\end{array}$ & (Diomandé et al., 2012) \\
\hline A. geocarpum & Ivory Coast & Rhizomes & $\begin{array}{l}\beta \text {-pinene }(22.7 \%) \text {, cyperene (11.8\%), caryophyllene } \\
\text { oxide }(10.5 \%)\end{array}$ & (Diomandé et al., 2012) \\
\hline A. giganteum & Africa Republic & Stems & $\begin{array}{l}\text { Linalool }(28.0 \%) \text {, linalyl acetate }(11.5 \%), \alpha \text {-terpineol } \\
(5.5 \%)\end{array}$ & (De Bernardi et al., 1981) \\
\hline A. giganteum & Gabon & Leaves & $\begin{array}{l}\text { cis-pinocamphone }(54.0 \%) \text {, cis-pinocamphone }(10.1 \%) \text {, } \\
\text { trans-verbenol }(2.1 \%)\end{array}$ & (Agnaniet et al., 2004) \\
\hline A. giganteum & Gabon & Rhizomes & $\begin{array}{l}\text { caryophyllene oxide }(30.4 \%), \quad \beta \text {-caryophyllene }(10.5 \%) \text {, } \\
\beta \text {-caryophylla-4(14),8(15)-dien-5-ol }(4.6 \%)\end{array}$ & (Agnaniet et al., 2004) \\
\hline A. giganteum & Congo Republic & Seeds & $\begin{array}{l}\beta \text {-pinene }(340.0 \mathrm{~g} / \mathrm{kg}), 1,8 \text {-cineol }(170 \mathrm{~g} / \mathrm{kg}) \text {, } \beta \text {-selinene } \\
(230.0 \mathrm{~g} / \mathrm{kg})\end{array}$ & (Ngakegni et al., 2013) \\
\hline A. giganteum & Congo Republic & Husks & $\begin{array}{l}\alpha \text {-selinene }(204.5 \mathrm{~g} / \mathrm{kg}) \text {, linalool }(188.9 \mathrm{~g} / \mathrm{kg}), \alpha \text {-pinene } \\
(143.4 \mathrm{~g} / \mathrm{kg})\end{array}$ & (Ngakegni et al., 2013) \\
\hline A. hanburyi & Yaounde, Cameroon & Leaves & $\beta$-pinene $(51.9 \%), \alpha$-pinene $(8.5 \%)$, limonene $(7.0 \%)$ & (Amvam et al., 2002) \\
\hline A. hanburyi & Yaounde, Cameroon & Seeds & $\begin{array}{l}(E, E) \text {-farnesol }(27.3 \%) \text {, linalool }(19.0 \%) \text {, terpinolene } \\
(8.2 \%)\end{array}$ & (Amvam et al., 2002) \\
\hline A. latifolium & Oyo State, Nigeria & Leaves & $\begin{array}{l}\text { 1,8- cineole }(45.05 \%), \beta \text {-pinene }(20.97 \%) \\
\text { cyclofenchene }(7.82)\end{array}$ & $\begin{array}{l}\text { (Olagoke \& Amusat, } \\
\text { 2019) }\end{array}$ \\
\hline A. latifolium & Yamoussoukro, Ivory Coast & Leaves & $\begin{array}{l}\beta \text {-pinene }(51.6 \%) \text { and } \beta \text {-caryophyllene (12.3\%), } \\
\text { sabinene }(7.6 \%)\end{array}$ & (Tia et al., 2011) \\
\hline A. letestuanum & Bamendjida, Cameroon & Seeds & $\begin{array}{l}\text { (E)-nerolidol }(88.0 \%) \text {, linalool }(2.2 \%) \text {, humulene } \\
\text { epoxide II }(1.3 \%)\end{array}$ & (Nguikwie et al., 2013) \\
\hline A. letestuanum & Bamendjida, Cameroon & Pericarps & $\begin{array}{l}\beta \text {-pinene }(38.5 \%) \text {, linalool ( } 10.1 \%) \text {, caryophyllene oxide } \\
(8.9 \%)\end{array}$ & (Nguikwie et al., 2013) \\
\hline A. letestuanum & Bamendjida, Cameroon & Leaves & $\begin{array}{l}\text { caryophyllene oxide }(23.7 \%), \beta \text {-caryophyllene }(18.4 \%) \text {, } \\
\beta \text {-pinene }(13.4 \%)\end{array}$ & (Nguikwie et al., 2013) \\
\hline A. letestuanum & Bamendjida, Cameroon & Rhizomes & $\beta$-pinene $(32.9 \%)$, cyperene $(4.9 \%), \beta$-pinene $(5.9 \%)$ & (Nguikwie et al., 2013) \\
\hline A. letestuanum & Yaounde, Cameroon & Seeds & $\begin{array}{l}\text { (E)-nerolido }(67.0 \%) \text {, linalool }(7.0 \%),(E, E) \text {-farnesol } \\
(3.4 \%)\end{array}$ & (Amvam et al., 2002) \\
\hline A. longiscapum & Ivory Coast & Leaves & $\begin{array}{l}\beta \text {-pinene }(42.6 \%), \beta \text {-caryophyllene }(25.4 \%), \alpha \text {-pinene } \\
(5.2 \%)\end{array}$ & (Diomandé et al., 2012) \\
\hline A. longiscapum & Ivory Coast & Rhizomes & $\beta$-pinene $(40.2 \%)$, linalool (27.4\%), $\alpha$-pinene (5.3\%) & (Diomandé et al., 2012) \\
\hline A. melegueta & Ojo Lagos, Nigeria & Seeds & $\begin{array}{l}\text { 2-octyl acetate }(60.4 \%) \text {, linalyl acetate }(16.5 \%) \text {, } \\
\alpha \text {-humulene }(6.0 \%)\end{array}$ & (Lawal et al., 2017) \\
\hline A. melegueta & Ibadan, Nigeria & Seeds & $\begin{array}{l}\beta \text {-humulene }(60.9 \%), \beta \text {-caryophyllene }(21.7 \%) \text {, } \\
\text { humulene oxide II }(5.5 \%)\end{array}$ & $\begin{array}{l}\text { (Ajaiyeoba \& Ekundayo, } \\
\text { 1999) }\end{array}$ \\
\hline A. melegueta & Central African Republic & Leaves & $\begin{array}{l}\beta \text {-pinene }(32.8 \%), \beta \text {-caryophyllene }(9.6 \%), \beta \text {-humulene } \\
(6.7 \%),\end{array}$ & (Lamaty et al., 1993) \\
\hline A. melegueta & Central African Republic & Seeds & $\begin{array}{l}\beta \text {-pinene }(37.0 \%) \text {, germacrene D }(16.9 \%), \\
\beta \text {-caryophyllene }(13.4 \%),\end{array}$ & (Lamaty et al., 1993) \\
\hline A. melegueta & South West Nigeria & Leaves & $\begin{array}{l}\text { Myrtenyl acetate }(29.06 \%) \text {, isolimonene }(19.47 \%) \text {, } \\
\beta \text {-elemene } \\
(8.84 \%)\end{array}$ & (Owokotomo, 2014) \\
\hline A. melegueta & South West Nigeria & Stem & $\begin{array}{l}\text { Caryophyllene oxide }(19.70 \%) \text {, myrtenyl acetate } \\
(14.70 \%) \text {, } \\
\beta \text {-eudesmene }(10.83 \%)\end{array}$ & (Owokotomo, 2014) \\
\hline A. melegueta & South West Nigeria & Roots & $\begin{array}{l}\text { Myrtenyl acetate }(22.70 \%) \text {, pinocarvyl acetate } \\
(11.50 \%) \text {, cyperene }(8.96 \%)\end{array}$ & (Owokotomo, 2014) \\
\hline A. melegueta & South West Nigeria & Seeds & $\begin{array}{l}\beta \text {-caryophyllene }(48.78 \%), \beta \text {-caryophyllene }(32.50 \%) \\
\text { and linalool }(5.40 \%)\end{array}$ & (Owokotomo, 2014) \\
\hline
\end{tabular}


Van et al.

Table 1: (Continued)

\begin{tabular}{|c|c|c|c|c|}
\hline Scientific name & Origin & Part & Major Components & References \\
\hline A. melegueta & $\begin{array}{l}\text { Bayelsa State, } \\
\text { Nigeria. }\end{array}$ & Seeds & $\begin{array}{l}\text { Carvone (13.47\%), menthol (11.88\%), methone } \\
(9.07 \%)\end{array}$ & (Owokotomo, 2014) \\
\hline A. melegueta & Akure, Nigeria & Leaves & $\begin{array}{l}\text { Myrtenyl acetate }(29.06 \%) \text {, limonene (19.45\%), } \\
\beta \text {-elemene }(8.84 \%)\end{array}$ & (Owokotomo, 2018) \\
\hline A. melegueta & Akure, Nigeria & Stems & $\begin{array}{l}\text { Caryophyllene oxide }(19.7 \%) \text {, myrtenyl acetate } \\
(14.7 \%), \beta \text {-eudesmene }(10.83 \%)\end{array}$ & (Owokotomo, 2018) \\
\hline A. melegueta & Akure, Nigeria & Seeds & $\alpha$-caryophyllene (48.78\%), $\beta$-caryophyllene $(32.5 \%)$ & (Owokotomo, 2018) \\
\hline A. melegueta & Akure, Nigeria & Rhizomes & $\begin{array}{l}\text { Myrtenyl acetate }(22.7 \%) \text {, pinocarvyl acetate }(11.5 \%) \text {, } \\
\text { cyperene }(8.96 \%)\end{array}$ & (Owokotomo, 2018) \\
\hline A. melegueta & Akure, Nigeria & Seeds & $\begin{array}{l}\text { Eugenol ( } 82.2 \%), \alpha \text {-caryophyllene, } \beta \text {-caryophyllene } \\
(3.27 \%)\end{array}$ & (Adefegha et al., 2017) \\
\hline A. melegueta & $\begin{array}{l}\text { Lagos State, } \\
\text { Nigeria }\end{array}$ & Leaves & $\begin{array}{l}\text { sabinene }(35.9 \%) \text {, } \alpha \text {-pinene (15.0 \%), } \beta \text {-caryophyllene } \\
(9.7 \%)\end{array}$ & (Lawal et al., 2015) \\
\hline A. melegueta & Foumbam, Cameroon & Fruits & $\begin{array}{l}\text { 1,8-cineole }(58.5 \%), \alpha \text {-terpineol (19.4\%), } \beta \text {-pinene } \\
(7.1 \%)\end{array}$ & (Kamte et al., 2017) \\
\hline A. melegueta & Mbalmayo, Cameroon & Fruits & $\begin{array}{l}\alpha \text {-Humulene (48.9\%), Humulene oxide II }(26.4 \%) \text {, } \\
\text { Caryophyllene oxide }(17.9 \%)\end{array}$ & (Menut \& Lamaty, 1991) \\
\hline A. pruinosum & Fontem, Cameroon & Seeds & $\begin{array}{l}\text { (E)-nerolidol (95.1\%), } \beta \text {-ocimene (1.6\%), } \alpha \text {-bisabolol } \\
(0.5 \%)\end{array}$ & (Nguikwie et al., 2013) \\
\hline A. pruinosum & Fontem, Cameroon & Pericarps & $\begin{array}{l}\beta \text {-pinene }(29.0 \%), 1,8 \text {-cineole }(1.4 \%) \text {, caryophyllene } \\
\text { oxide }(9.0 \%)\end{array}$ & (Nguikwie et al., 2013) \\
\hline A. pruinosum & Fontem, Cameroon & Leaves & $\begin{array}{l}\beta \text {-caryophyllene ( } 47.7 \%), \beta \text {-pinene }(27.8 \%), \\
\text { caryophyllene oxide }(6.2 \%)\end{array}$ & (Nguikwie et al., 2013) \\
\hline A. pruinosum & Fontem, Cameroon & Rhizomes & $\beta$-pinene $(34.3 \%)$, linalool (5.5\%), cyperene $(4.4 \%)$ & (Nguikwie et al., 2013) \\
\hline A. pruinosum & Yaounde, Cameroon & Leaves & $\begin{array}{l}\beta \text {-pinene }(31.4 \%), \beta \text {-caryophyllene }(25.8 \%), \\
\text { caryophyllene oxide }(9.1 \%)\end{array}$ & (Amvam et al., 2002) \\
\hline A. pruinosum & Yaounde, Cameroon & Seeds & $\begin{array}{l}\text { (E)-nerolido (91.7\%), } \beta \text {-ocimene (1.0\%), linalool } \\
(0.9 \%)\end{array}$ & (Amvam et al., 2002) \\
\hline A. pruinosum & Dshang, Cameroon & Leaves & $\begin{array}{l}\beta \text {-pinene }(31.4 \%), \beta \text {-caryophyllene }(25.8 \%), \\
\text { caryophyllene oxide }(9.1 \%)\end{array}$ & (Menut et al., 1994) \\
\hline A. pruinosum & Dshang, Cameroon & Seeds & $\begin{array}{l}\text { (E)-nerolido ( } 91.7 \%) \text {, } \beta \text {-ocimene }(1.0 \%) \text {, linalool } \\
(0.9 \%)\end{array}$ & (Menut et al., 1994) \\
\hline A. sanguineum & Bujumbura, Burundi & Seeds & $\begin{array}{l}\text { 1,8-cineole }(38.5 \%) \text {, } \alpha \text {-terpinyl acetate }(9.6 \%) \text {, geranyl } \\
\text { acetate }(9.4 \%)\end{array}$ & (Hari et al., 1994) \\
\hline A. sceptrum & Ivory Coast & Rhizomes & $\begin{array}{l}\beta \text {-pinene }(12.7 \%) \text {, caryophyllene oxide }(10.0 \%), \\
\text { cyperene }(6.0 \%)\end{array}$ & (Cheikh-Ali et al., 2011) \\
\hline A. sceptrum & Ivory Coast & Leaves & $\begin{array}{l}\beta \text {-pinene }(15.1 \%), 1,8 \text {-cineole }(12.1 \%), \beta \text {-humulene } \\
(10.1 \%)\end{array}$ & (Diomandé et al., 2012) \\
\hline A. sceptrum & Ivory Coast & Rhizomes & $\begin{array}{l}\beta \text {-elemene (10.4\%), } \beta \text {-pinene (7.8\%), } \beta \text {-humulene } \\
(6.7 \%)\end{array}$ & (Diomandé et al., 2012) \\
\hline A. sceptrum & Abomey calavi, Benin & Limbos & $\begin{array}{l}\beta \text {-caryophyllene (33.4\%), } \beta \text {-pinene }(28.4 \%), \beta \text {-humulene } \\
(10.6 \%)\end{array}$ & (Adjalian et al., 2014) \\
\hline A. sceptrum & Abomey calavi, Benin & $\begin{array}{l}\text { Leaf } \\
\text { sheaths }\end{array}$ & $\beta$-pinene $(42.4 \%), \beta$-pinene $(5,7 \%)$ & (Adjalian et al., 2014) \\
\hline A. sceptrum & $\begin{array}{l}\text { Abomey } \\
\text { calavi, Benin }\end{array}$ & Rhizomes & $\begin{array}{l}\beta \text {-pinene }(15.9 \%), \beta \text {-terpineol }(15.2 \%), \beta \text {-caryophyllene } \\
(13.9 \%)\end{array}$ & (Adjalian et al., 2014) \\
\hline A. sceptrum & Lagos State, Nigeria & Seeds & $\begin{array}{l}\text { 1,8-cineole (81.9\%), } \beta \text {-terpineol (10.1\%), } \beta \text {-pinene } \\
(4.8 \%)\end{array}$ & (Owolabi et al., 2010) \\
\hline A. strobilaceum & Ivory Coast & Leaves & $\begin{array}{l}\beta \text {-caryophyllene }(36.1 \%), \beta \text {-selinene }(15.9 \%) \text {, } \\
\text { germacrene A }(10.8 \%)\end{array}$ & (Diomandé et al., 2012) \\
\hline A. stipulatum & Owando, Congo Republic & Seeds & $\begin{array}{l}\beta \text {-pinene }(428.2 \mathrm{~g} / \mathrm{kg}), \beta \text {-caryophyllene }(91.7 \mathrm{~g} / \mathrm{kg}) \text {, } \\
\alpha \text {-humulene }(77.4 \mathrm{~g} / \mathrm{kg})\end{array}$ & (Ngakegni et al., 2013) \\
\hline A. stipulatum & Owando, Congo Republic & Husks & $\begin{array}{l}\beta \text {-pinene }(235.2 \mathrm{~g} / \mathrm{kg}), 1,8 \text {-cineol }(143.6 \mathrm{~g} / \mathrm{kg}), \\
\alpha \text {-terpineol }(122.1 \mathrm{~g} / \mathrm{kg})\end{array}$ & (Ngakegni et al., 2013) \\
\hline A. stipulatum & Kinshasa, Congo Republic & Leaves & Thymol $(34.0 \%)$, eugenol $(7.2 \%)$, p-cymene $(6.2 \%)$ & (Cimanga et al., 2002) \\
\hline A. sulcatum & Mbalmayo, Cameroon & Fruits & $\begin{array}{l}\beta \text {-guaiene }(26.7 \%), \beta \text {-guaiene oxide (18.1\%), limonene } \\
(10.5 \%)\end{array}$ & (Menut \& Lamaty, 1991) \\
\hline A. sulcatum & Afan Oyo, Cameroon & Leaves & $\begin{array}{l}\beta \text {-Caryophyllene }(23.3 \%), \beta \text {-Phellandrene }(10.6 \%) \text {, } \\
\beta \text {-Pinene }(9.5 \%)\end{array}$ & (Nyegue et al., 2014) \\
\hline
\end{tabular}

\section{Aframomum melegueta K. Schum.}

Synonyms: Aframomum grana-paradisi (L.) K.Schum., A. meleguetella K.Schum., Alexis grandiflora (Sm.) Salisb., Alpinia grana-paradisi (L.) Moon, Amomum elatum Salisb., A. granaparadisi L., A. grandiflorum Sm., A. melegueta Roscoe, A. melegueta var. violacea Ridl., Cardamomum grana-paradisi (L.) Kuntze, C. grandiflorum (Sm.) Kuntze, Torymenes officinalis Salisb.

A. melegueta is commonly known as "lligator pepper "or "Grain of paradise" (Lawal et al., 2007). It is a perennial species native to western Africa. The A. melegueta seeds are used as a spice as well as 
treatment of diarrhea, stomachaches, and snakebites (Belayneh $\&$ Bussa, 2014). Studies reported that the seeds of this species possessed pharmacological properties such as cytoprotection, anti-ulcer and antimicrobial effects (Kamtchouing, 2002). The major constituents of A. melegueta were mainly composed of sesquiterpene hydrocarbons, followed by oxygenated monoterpenes, oxygenated sesquiterpenes and monoterpene hydrocarbons. The leaf and root essential oils of A. melegueta collected from south west Nigeria contained myrtenyl acetate as the most abundant compound, followed by isolimonene, $\gamma$-elemene, pinocarvyl acetate and cyperene. Additionally, the major constituents in stem oil had caryophyllene oxide, myrtenyl acetate and $\beta$-eudesmene as main constituents while the seed oil was made of $\alpha$-caryophyllene, $\beta$-caryophyllene and linalool (Owokotomo, 2014). Meanwhile, the seed oil of A. melegueta grown in Bayelsa State, Nigeria was found to be rich in carvone, menthol and methone (Owokotomo, 2014). The leaf oil of this species from Lagos State, Nigeria was dominated by sabinene, $\alpha$-pinene and $\beta$-caryophyllene (Lawal et al., 2015).

Another sample of A. melegueta collected from Akure, Nigeria has been reported to possess a wide diversity of chemical composition in essential oils from different plant parts. Accordingly, myrtenyl acetate, limonene and $\gamma$-elemene were the major components in the leaf oil. The stem oil was characterized by the predominance of caryophyllene oxide, myrtenyl acetate and $\beta$-eudesmene. The seed oil was made of $\alpha$-caryophyllene and $\beta$-caryophyllene while essential oil of rhizomes was found to be rich in myrtenyl acetate, pinocarvyl acetate and cyperene (Owokotomo, 2018). Meanwhile, the seed oil of this species from the same location (Akure, Nigeria) that reported from another study had eugenol, $\alpha$-caryophyllene, $\beta$-caryophyllene as the major compounds (Adefegha et al., 2017). In addition, the leaf and seed essential oils of A. melegueta from the Central African Republic contained $\beta$-pinene, $\beta$-caryophyllene, $\alpha$-humulene and germacrene $\mathrm{D}$ as the major components (Lamaty et al., 1993). The seed oil of A. melegueta from Ojo Lagos, Nigeria had 2-octyl acetate, linalyl acetate and $\alpha$-humulene as the main compounds (Lawal et al., 2017) while $\alpha$-humulene, $\beta$-caryophyllene and humulene oxide II were shown by the seed oil from Ibadan, Nigeria towards the same species (Pavela et al., 2016). Finally, the fruit essential oil of A. melegueta collected from Foumbam, Cameroon presented a characteristic composition with 1,8-cineole, $\alpha$-terpineol and $\beta$-pinene as the major compounds (Kamte et al., 2017) whereas the fruit oil from Mbalmayo, Cameroon was mainly composed of $\alpha$-humulene, humulene oxide II and caryophyllene oxide (Menut et al., 1991).

\section{Aframomum daniellii (Hook.f.) K.Schum.}

Synonyms: Amomum afzelii Hook. f., Amomum angustifolium T.Hanb., Amomum daniellii Hook.f., Cardamomum daniellii (Hook.f.) Kuntze.

A. daniellii is commonly referred to as "African cardamom" (Menut et al., 1991). It is a large robust perennial plant and is widely found throughout central and west African countries
(Adegoke et al., 2000). Seeds and roots of this species has been known for their traditional medicine to use as antihelminthic, laxative and purgative (Bouquet, 1969). Rhizome extracts were effectual in the therapy of toothache and body odor. In addition, A. daniellii seeds were used to the flavor foodstuffs because of their olive-brown and shiny characteristics (Tane et al., 2005).

The major components of A. daniellii essential oils were characterized by the predominance of monoterpene hydrocarbons, followed by oxygenated monoterpenes and sesquiterpenoid hydrocarbons. The essential oils obtained from various plant parts of A. daniellii grown in Akwa Ibom, Nigeria have been reported. Accordingly, the stem, rhizome and pod oils possessed $\beta$-pinene, $\alpha$-phellandrene and $\gamma$-terpinene as the major compounds. The oil of leaves was found to be rich in $\beta$-pinene, caryophyllene oxide and $\beta$-caryophyllene while the seed oil was made of 1,8-cineole, $\alpha$-terpineol, $\beta$-pinene (Essien et al., 2017). Similarly, the wide diversity of chemical composition in essential oils from different plant parts of A. daniellii from Bafoussam, Cameroon has been presented. For instance, the seed essential oil was dominated by 1,8-cineole, $\alpha$-terpineol, geraniol and $\beta$-pinene (Pavela et al., 2016; Dongmo SCM et al., 2019; Meffo et al., 2019). The essential oil obtained from pericarps contained $\beta$-pinene, sabinene and linalool as the major components while the leaf oil was characterized by the predominance of sabinene, (E)-caryophyllene and $\beta$-pinene (Pavela et al., 2016; Kamte et al., 2017). Also, the fruit oil of A. daniellii from Balengou, Cameroon was mainly made of 1,8-cineole, limonene and $\beta$-pinene (Menut et al., 1991). The leaf oil of A. daniellii from Lagos State, Nigeria was mainly composed of $\beta$-pinene, limonene and $\alpha$-pinene whereas 1,8-cineole, linalool and terpinen-4-ol were the main compounds in the seed oil (Lawal et al., 2017). The major volatile components of A. daniellii seeds from Rivers State, Nigeria included 1,8-cineole, $\beta$-pinene and $\alpha$-terpineol (Emmanuel et al., 2020) while eugenol, 1,8-cineole and $\beta$-caryophyllene were the major components in the seed oil collected from Akure, Nigeria (Adefegha et al., 2017). In addition, the pod oil from Ibadan, Nigeria (Olosunde et al., 2015) and the fruit oil from São Tomé and Príncipe (Martins et al., 2001) were found to be rich in 1,8-cineole, $\beta$-pinene and $\alpha$-terpineol.

\section{Aframomum corrorima (A.Braun) P.C.M.Jansen.}

Synonyms: Aframomum korarima (C.Pereira) Engl., A. usambarense Lock, Amomum corrorima A.Braun, A. corrorima P.J.Braun, A. korarima C.Pereira.

A. corrorima is also known as "Korarima", "Ethiopian cardamom" or "false cardamom" and is native to western Ethiopia. It is an aromatic perennial herb and usually large in size (1-2 meters high). In Ethiopian cuisine, this plant was commonly used as an ingredient in berbere, mitmita, awaze. Additionally, the seeds of Korarima were used in traditional medicine as a laxative, tonic and carminative (Zakir, 2018).

The major components of A. corrorima essential oils were mainly composed of oxygenated monoterpenes, followed 
by monoterpene hydrocarbons. The major components of the essential oil obtained from seeds of A. corrorima grown in southern Ethiopia included $\beta$-caryophyllene, $\beta$-pinene and caryophyllene oxide whereas the rhizome oil possessed $\gamma$-terpinene, $\beta$-pinene and $\beta$-caryophyllene as the major compounds (Eyob et al., 2008). The pod essential oil of A. corrorima from southern Ethiopia was mainly composed of $\gamma$-terpinene $\beta$-pinene and $\alpha$-phllandrene while 1,8-cineole and sabinene were the major components of the seed oils from southern Ethiopia (Eyob et al., 2007) and Merkato, Ethiopia (Hymete et al., 2006). The major volatile components of A. corrorima husks from Merkato, Ethiopia included (E)-nerolidol, $\beta$-caryophyllene and caryophyllene oxide (Hymete et al., 2006). In addition, the seed oils of A. corrorima collected from Saudi Arabia and Madagascar contained 1,8-cineole as the most abundant compound (Baser \& Kürkçüoglu, 2001; Noumi et al., 2018). Followed by (E)-nerolidol, $\alpha$-terpinyl acetate (Baser $\&$ Kürkçüoglu, 2001) and terpinen-4-ol, limonene (Noumi et al., 2018).

\section{Aframomum cereum (Hook.f.) K.Schum.}

Synonyms: Aframomum sceptrum (Oliv. \& D.Hanb.) K.Schum., A. masuianum (De Wild. \& T.Durand) K.Schum., Amomum cereum Hook.f., A. masuianum De Wild. \& T.Durand, A. sceptrum Oliv. \& D.Hanb., Cardamomum cereum (Hook.f.) Kuntze, C. sceptrum (Oliv. \& D.Hanb.) Kuntze, Zerumbet autranii Heckel.

Aframomum cereum (Hook.f.) K.Schum. is commonly known as a synonym Aframomum sceptrum (Oliv. \& D.Hanb.) K.Schum. and also known as 'Oburo etu' or 'Ehin-edo' in Nigerian. This species extensively grows in humid forest regions of tropical Central Africa that the height reaches about 6 meters. In African traditional medicine, the extracts of A. sceptrum were used to treat dysentery and intestinal helminthes (Trypanosomiasis) (Okpekon et al., 2004). Limbo and leaf sheaths of this plant were used to cure digestive candidiasis and female infertility (Okpekon et al., 2004). Also, several bioactivities of A. sceptrum extracts, including antioxidant, antispasmodic and antimicrobial activities have been reported by previous studies (George, 2011).

A. sceptrum essential oils were often composed of relatively equal amounts of monoterpene hydrocarbons and oxygenated sesquiterpenes. The leaf oil isolated from A. sceptrum grown in Ivory Coast was found to be rich in $\beta$-pinene, 1,8 -cineole and $\alpha$-humulene while the rhizome essential oil was made of $\delta$-elemene, $\beta$-pinene and $\alpha$-humulene (Rana et al., 2010). Meanwhile, the rhizome oil of this species from the same location (Ivory Coast) that reported from another study had $\beta$-pinene, caryophyllene oxide and cyperene as the major compounds (Cheikh-Ali et al., 2011). In addition, $\beta$-pinene was the most abundant component in the essential oils from leaf sheaths and rhizomes collected from Abomey calavi, Benin, followed by $\alpha$-pinene, $\alpha$-terpineol and $\beta$-caryophyllene whereas the limbo oil showed $\beta$-caryophyllene, $\beta$-pinene and $\alpha$-humulene as the main components (Adjalian et al., 2014). Furthermore, the essential oil of seeds obtained from A. sceptrum from Lagos State, Nigeria was mainly attributed to the presence of 1,8-cineole, $\alpha$-terpineol and $\beta$-pinene (Owolabi et al., 2010).

\section{Aframomum giganteum (Oliv. \& D.Hanb.) K.Schum.}

Synonyms: Aframomum giganteum var. giganteum, A. giganteum var. puberulifolium Koechlin, Amomum giganteum Oliv. \& D.Hanb., Cardamomum giganteum (Oliv. \& D.Hanb.) Kuntze.

A. giganteum is a large species that can reach a height of up to 6 meters. This plant extensively grows in tropical regions of Central Africa. All plant parts of A. giganteum possess an extensive and characteristic flavor. Natives in Central Africa regions used several plant parts of this species such as fruits, leaves, seeds and stems as an indigenous medicine for its healing properties (Adjanohoun, 1998). Notably, the leaf decoction, fresh juice or macerated rhizomes were used by Congolese people to treat heart pains, cough, conjunctivitis and tooth pains (Bouic, 2001) (Awad \& Fink, 2018). The composition of essential oils isolated from A. giganteum have been reported by previous studies. Accordingly, the seed essential oil of A. giganteum collected from the Congo Republic was characterized by the predominance of $\beta$-pinene, 1,8-cineol and $\alpha$-selinene while the husk oil possessed $\alpha$-selinene, linalool and $\beta$-pinene as the major components (Ngakegni et al., 2013). In addition, the leaf oil of A. giganteum grown in Gabon was found to be rich in cis-pinocamphone, cis-pinocamphone and trans-verbenol while caryophyllene oxide, $\beta$-caryophyllene and $\beta$-caryophylla4(14),8(15)-dien-5-ol were the main compounds in the rhizome oil (Agnaniet et al., 2004). The major volatile components of the A. giganteum stems from the Africa Republic contained linalool, linalyl acetate and $\alpha$-terpineol (De Bernardi et al., 1981).

\section{Aframomum citratum (C.Pereira) K.Schum.}

Synonyms: Amomum citratum C.Pereira, Amomum macrolepis K.Schum., Cardamomum citratum (C.Pereira) Kuntz.

A. citratum is a herbaceous and perennial rhizomatous species throwing up stems to 3 meters tall (Burkil, 2000). This species extensively grows spontaneously in humid forest regions of tropical Africa, especially in Cameroon (Koechlin, 1665). Shoots and seeds of A. citratum were used as a green vegetable or a spice in Cameroon. Also, seeds were the major ingredient in "Mbongotjobi", a common condiment in Cameroon. In traditional medicine, seed extracts were used to treat stomach ache, lombalgies (Abondo, 1993), malaria, bacterial infections, cancers and as an aphrodisiac (Titanji et al., 2008) (Kuete et al., 2011).

The chemical composition of the essential oils isolated from A. citratum was characterized by the predominance of oxygenated monoterpenes. Geraniol was the most abundant compound in the essential oils of A. citratum seeds collected from Bafoussam and Yaounde Cameroon while the insignificant portion of the total included linalool, geranyl acetate and myrcene (Amvam et al., 2002; Meffo et al., 2019; Dongmo et al., 2019). 
In addition, the essential oil of A. citratum leaves grown in Yaounde Cameroon was dominated by $\beta$-pinene, $\alpha$-pinene and $\beta$-caryophyllene (Amvam et al., 2002). Finally, the essential oil of A. citratum seeds from Kribi, Cameroon was found to be rich in geraniol, linalool and myrcene (Chalchat et al., 1997).

\section{Aframomum pruinosum Gagnep.}

A. pruinosum is a large shrub (about 5 meters tall) growing naturally beneath the forest canopy of the western region of Cameroon, including Dschang, Fontem, Bafoussam and the central region of Mbalmayo. This species is also located in Gabon and Central Africa (Koechlin, 1965). Seeds of this species have a pleasant scent and slightly sweet flavor. In traditional medicine of Cameroon, these plants are used to cure sterility in women (Abondo, 1993).

The chemical composition of essential oils obtained from different plant parts of A. pruinosum mainly belonged to monoterpene hydrocarbons, followed by oxygenated monoterpenes and oxygenated sesquiterpenes. The specimens of this species collected from Fontem, Cameroon showed the wide diversity of chemical profiles in essential oils. For instance, the seed oil possessed (E)-nerolidol, $\beta$-ocimene, $\alpha$-bisabolol as the major compounds. The pericarp oil contained a main proportion of $\beta$-pinene, 1,8-cineole and caryophyllene oxide. $\beta$-caryophyllene, $\beta$-pinene and caryophyllene oxide were found as the major components in the leaf essential oil while the rhizome oil was characterized by the predominance of $\beta$-pinene, linalool and cyperene (Nguikwie et al., 2013). Furthermore, the leaf essential oils of A. pruinosum collected from Yaounde and Dshang, Cameroon possessed $\beta$-pinene, $\beta$-caryophyllene and caryophyllene oxide as the main compounds whereas the seed oil was rich in (E)-nerolido, $\beta$-ocimene and linalool (Menut et al., 1994; Amvam et al., 2002).

\section{Aframomum letestuanum Gagnep.}

A. letestuanum is an herbaceous plant that has a height reaching 3 meters. This species is commonly cultivated in the western Cameroon for the harvesting of fruits. In traditional medicine, A. letestuanum was used to treat muscular pains, nausea, vomiting, hemorrhage (Nguenang et al., 2018) and and female infertility (Telefo et al., 2011). Recent studies reported that leaf extracts of A. letestuanum possessed the antimicrobial activities as well as contained several biological compounds, including alkaloids, flavonoids, polyphenols, saponins, steroids, tannins and triterpenes (Nguenang et al., 2018). The chemical profiles of essential oils obtained from A. letestuanum were mainly characterized by the presence of monoterpene hydrocarbons and oxygenated sesquiterpenes, followed by oxygenated monoterpenes. The seed essential oils of A. letestuanum collected from Yaounde and Bamendjida, Cameroon possessed (E)-nerolidol and linalool as the main compounds (Amvam et al., 2002; Nguikwie et al., 2013). The main components of the pericarp essential oil from Bamendjida, Cameroon were identified to be $\beta$-pinene, linalool and caryophyllene oxide. Also, the principal compounds of the leaf oil from Bamendjida region were caryophyllene oxide, $\beta$-caryophyllene and $\beta$-pinene while the main components in the rhizome oil were found to be $\beta$-pinene, cyperene and $\alpha$-pinene (Nguikwie et al., 2013).

\section{Aframomum alboviolaceum (Ridl.) K.Schum.}

Synonyms: Aframomum biauriculatum K.Schum., A. candidum Gagnep., A. latifolium K.Schum., A. macrospermum (Sm.) Burkill, A. stipulatum (Gagnep.) K.Schum., Amomum alboviolaceum Ridl., A. bitacoum Gagnep., A. latifolium Afzel., A. macrospermum Sm., A. stipulatum Gagnep., Cardamomum latifolium Kuntze, Ceratanthera beaumetzii Heckel.

A. alboviolaceum is an herbaceous species reaching up 3 meters tall that is extensively distributed in Africa (Inkoto et al., 2021). The rhizomes of this plant are used as a food in Ivory Coast. In African traditional medicine, A. alboviolaceum has been used to cure many diseases. For example, all plant parts were used to treat diuretic, anti-helminthic, anti-parasitic, anti-malaria and fever in Cameroon (Titanji et al., 2008). In the Democratic Republic of the Congo, A. alboviolaceum leaves were used to cure headache, gastritis, cough, fever, amoebic dysentery and haemorrhoids (Inkoto et al., 2021), malaria, headaches, myoma, hypertension, gastritis and pruritis, pruritus and filarial (Ngbolua et al., 2016). In addition, A. alboviolaceum extracts also had the bioactivities such as antimicrobial, antioxidant, anti-sickling, antimalarial, anticancer effects (Kwazou et al., 2009; Bongo, 2017). Several bioactive compounds, including phenolic acids, anthocyanins, flavonoids, iridoids, tannins, alkaloids, coumarins, anthraquinones and tri-terpenes have been identified in the extracts of A. alboviolaceum (Kwazou et al., 2009; Bongo, 2017). The chemical components of the essential oils isolated from A. alboviolaceum were characterized by the predominance of mono-oxygenated sesquiterpenes and diterpenes, followed by di-oxygenated sesquiterpenes and sesquiterpenes hydrocarbons. The rhizome oil of A. alboviolaceum (Ridl.) K.Schum. colleted from Contuboel, Guinea-Bissau was found to be rich in intermedeol, carotol and spathulenol (Abreu \& Noronha, 1997). Also, A. biauriculatum K.Schum., a synonym of A. alboviolaceum (Ridl.) K.Schum., collected from Zambia has been investigated the composition of essential oils. Accordingly, the leaf oil of this species possessed $\beta$-pinene, $\beta$-caryophyllene, $\alpha$-pinene as the major compounds while the main components in the rhizome oil were $\beta$-pinene, 1,8-cineole and $\alpha$-terpineol (Chisowa et al., 1998).

\section{Other Aframomum Species}

Other Aframomum species had a lesser report by reason of their limit of distribution and commercial interest. For instance, the essential oils obtained from pericarps and rhizomes of A. dalzielii Hutch. collected from Fontem, Cameroon were comprised mainly of $\beta$-pinene, sabinene and $\alpha$-pinene. The major constituents of the leaf oil from the same location were $\beta$-caryophyllene, $\beta$-pinene and caryophyllene oxide while $(E)$ nerolidol and 2-heptyl acetate were the compounds occurring in higher amounts in the seed oil (Nguikwie et al., 2013). In addition, the leaf essential oil of A. hanburyi K.Schum. collected from Yaounde, Cameroon was mainly characterized by the 
presences of $\beta$-pinene, $\alpha$-pinene and limonene whereas $(E, E)$ farnesol, linalool and terpinolene were the major constituents in the seed oils towards the same species (Amvam et al., 2002). Also, the main components of the fruit essential oil of $A$. sulcatum (Oliv. \& D.Hanb. ex Baker) K.Schum. from Mbalmayo, Cameroon were identified to be $\alpha$-guaiene, $\delta$-guaiene oxide and limonene (Lamaty et al., 1993) while the leaf oil of this species from Afan Oyo, Cameroon contained $\beta$-caryophyllene, $\beta$-phellandrene, $\alpha$-pinene as the major compounds (Nyegue et al., 2014).

The quantitatively significant components of the leaf oil of A. elliotti (Baker) K.Schum. grown in Ivory Coast were $\beta$-pinene, $\beta$-caryophyllene and $\alpha$-pinene while the rhizome oil possessed linalool, 1,8-cineole, $\beta$-pinene as the major constituents (Diomandé et al., 2012). The leaf essential oil obtained from A. geocarpum Lock \& J.B.Hall, another species collected from Ivory Coast, contained $\beta$-caryophyllene, $\alpha$-humulene and $\beta$-pinene as the main components while the rhizome oil was found to be rich in $\beta$-pinene, cyperene and caryophyllene oxide (Diomandé et al., 2012). Furthermore, the rhizome and leaf essential oils of A. longiscapum (Hook.f.) K.Schum. collected from Ivory Coast possessed $\beta$-pinene as the most abundant compound, followed by $\beta$-caryophyllene, linalool and $\alpha$-pinene (Diomandé et al., 2012). The leaf oil of A. strobilaceum (Sm.) Hepper from Ivory Coast possessed $\beta$-caryophyllene, $\beta$-selinene and germacrene $\mathrm{A}$ as the main constituents (Diomandé et al., 2012). Moreover, the main components of the leaf essential oil of A. latifolium K.Schum. from Ivory Coast were identified to be $\beta$-pinene and $\beta$-caryophyllene, sabinene (Tia et al., 2011) while this leaf oil of this species from Oyo State, Nigeria was mainly characterized by the presences of 1,8-cineole, $\beta$-pinene and cyclofenchene (Olagoke \& Amusat, 2019; Adjalian et al., 2014; Adjalian et al., 2014).

The essential oils of several plant parts of A. stipulatum (Gagnep.) K.Schum. from the Congo Republic have been reported. For instance, the principal compounds of the leaf oil from Kinshasa region were thymol, eugenol and p-Cymene. The husk oil of this species possessed $\beta$-pinene, 1,8-cineol and $\alpha$-terpineol as the major components while $\beta$-pinene, $\beta$-caryophyllene and $\alpha$-humulene were the dominant compounds of the seed oil (Ngakegni et al., 2013). In addition, the essential oils of A. exscapum (Sims) Hepper collected from various locations of the Ivory Coast have been reported. As a consequence, the leaf oils from Malamalasso, Nianda North, Nianda South and Nianda East of Ivory Coast contained 1,8-cineole, $\alpha$-pinene and germacrene $\mathrm{D}$ as the major compounds whereas the 1,8-cineole, (E)-nerolidol, $\alpha$-terpineol were the main components of this sample from Assouba, Ivory Coast (Muriel et al., 2011). Moreover, the major constituents of essential oil A. sanguineum seeds grown in Bujumbura, Burundi were found to be 1,8-cineole, $\alpha$-terpinyl acetate and geranyl acetate (Hari et al., 1994). The seed essential oil of A. angustifolium (Sonn.) K.Schum. from Madagascar contained a main proportion of $\beta$-pinene, $\beta$-caryophyllene and cis-pinocarvyl acetate (Baser $\&$ Kürkçüoglu, 2001).

\section{CONCLUSIONS}

The present review provides an overview of all the published studies on the chemical constituents of the essential oils isolated from Aframomum species. The various Aframomum plants collected from different regions had a diversity of chemical constituents. The essential oils of Aframomum are richer in chemical components of commercial interest in pharmaceutical industries. The result of the present review will contribute to the beneficial potentials and give the evidence for future applications of Aframomum species in the medicinal and pharmaceutical industries.

\section{AUTHOR'S CONTRIBUTIONS}

This study was designed Hong Thien Van. All authors searched and handled the data. Hong Thien Van prepared the manuscript and resolved all the queries of reviewers.

\section{REFERENCES}

Abondo, R. (1993). Plantes Mbdicinales, condimentaires et mbdicinales du genre Aframomum (Zingiberaceae). These de Doctorat, Université de Yaoundé.

Abreu, P. M., \& Noronha, R. G. (1997). Volatile Constituents of the Rhizomes of Aframomum alboviolaceum (Ridley) K. Schum. from Guinea-Bissau. Flavour and Fragrance Journal, 12(2), 79-83. https://doi.org/10.1002/ (SICI)1099-1026(199703)12:2<79:AID-FFJ617>3.0.CO;2-7

Adebayo, T. A., Gbolade, A. A., \& Olaifa, J. I. (1999). Comparative study of toxicity of some essential oils to larvae of three mosquito species. Nigerian Journal of Natural Products and Medicine, 3, 74-76.

Adefegha, S. A., Olasehinde, T. A., \& Oboh, G. (2017). Essential oil composition, antioxidant, antidiabetic and antihypertensive properties of two Afromomum species. Journal of Oleo Science, 66(1), 51-63. https://doi.org/10.5650/jos.ess16029

Adegoke, G. O., Fasoyiro, S. B., \& Skura, B. (2000). Control of microbial growth, browning and lipid oxidation by the spice Aframomum danielli. European Food Research and Technology, 211(5), 342-345. https://doi.org/10.1007/s002170000170

Adjalian, E., D Bothon, F. T., Yehouenou, B., Noudogbessi, J. P., Figueredo, G., Avlessi, F., \& K Sohounhloue, D. C. (2014). GC/MS and GC/FID analysis and evaluation of antimicrobial performance of Aframomum sceptrum essential oils of Benin. World Journal of Pharmaceutical Sciences, 2(8), 787-792.

Adjanohoun, E. J. (1998). Medecine traditionnelle et pharmacopee: contribution ' aux etudes ethnobotaniques et floristiques en R ' epublique Populaire 'du Congo. ACCT.

Agnaniet, H., Menut, C., \& Bessière, J. M. (2004). Aromatic plants of tropical central Africa. Part XLIX+: Chemical composition of essential oils of the leaf and rhizome of Aframomum giganteum K. Schum from Gabon. Flavour and Fragrance Journal, 19(3), 205-209. https://doi. org/10.1002/ffj. 1403

Ajaiyeoba, E. O., \& Ekundayo, O. (1999). Essential oil constituents of Aframomum melegueta (Roscoe) K. Schum. seeds (Alligator pepper) from Nigeria. Flavour Fragrance Journal, 14(2), 109-111. https://doi.org/10.1002/(SICI)1099-1026(199903/04)14:2<109:AIDFFJ775>3.0.CO;2-M

Amadi, S. W., Zhang, Y., \& Wu, G. (2016). Research progress in phytochemistry and biology of Aframomum species. Pharmaceutical Biology, 54(11), 2761-2770. https://doi.org/10.3109/13880209.2016 .1173068

Amvam Z. P. H., Abondo, R., Biyiti, L., Menut, C., \& Bessière, J. M. (2002). Aromatic plants of Tropical Central Africa XXXVIII: Chemical composition of the essential oils from four Aframomum species collected in Cameroon (1). Journal of Essential Oil Research, 14(2), 95-98. https://doi.org/10.1080/10412905.2002.9699781

Awad, A. B., \& Fink, C. S. (2018). Recent advances in nutritional sciences phytosterols as anticancer dietary components: evidence and 
mechanism of action 1,2.

Baser, K. H. C., \& Kürkçüoglu, M. (2001). The essential oils of Aframomum corrorima (Braun) jJansen and $A$. angustifolium K. Schum. from Africa. Journal of Essential Oil Research, 13(3), 208-209. https://doi.org/10. 1080/10412905.2001.9699667

Belayneh, A., \& Bussa, N. F. (2014). Ethnomedicinal plants used to treat human ailments in the prehistoric place of Harla and Dengego valleys, eastern Ethiopia. Journal of Ethnobiology and Ethnomedicine, 10(1). https://doi.org/10.1186/1746-4269-10-18

De Bernardi, M., Mellerio, G., Paternoster-Colombo, M., Vidari, G., \& VitaFinzi, P. (1981). Constituents of essential oil of Aframomum giganteum. Planta Medica, 41(4), 359-365. https://doi.org/10.1055/s-2007-971727

Bongo, G. (2017). Antisickling, antioxidant and antibacterial activities of Afromomum alboviolaceum (Ridley) K. Schum, Annona senegalensis Pers. and Mondia whitei (Hook. f.) Skeels. American Journal of Laboratory Medicine, 2(4), 52. https://doi.org/10.11648/j. ajlm.20170204.13

Bouic, P. J. D. (2001). The role of phytosterols and phytosterolins in immune modulation: a review of the past 10 years. Current Opinion in Clinical Nutrition and Metabolic Care, 4(6), 471-475

Bouquet A. (1969). Féticheurs et médecine traditionnelle du Congo (Brazzaville). Orstom.

Burkil HM. (2000). The useful plants of West Tropical Africa. $2^{\text {nd }}$ edition, volume 5, Fa milies S-Z. Royal Botanic Gardens. Kew, Richmond.

Chalchat, J. C., Garry, R. P., Menut, C., Lamaty, G., Malhuret, R., \& Chopineau, J. (1997). Correlation between chemical composition and antimicrobial activity. VI. Activity of some african essential oils. Journal of Essential Oil Research, 9(1), 67-75. https://doi.org/10.10 80/10412905.1997.9700717

Cheikh-Ali, Z., Adiko, M., Bouttier, S., Bories, C., Okpekon, T., Poupon, E., \& Champy, P. (2011). Composition, and antimicrobial and remarkable antiprotozoal activities of the essential oil of rhizomes of Aframomum sceptrum K. Schum. (Zingiberaceae). Chemistry \& Biodiversity, 8(4). https://doi.org/10.1002/cbdv.201000216

Chisowa, E. H., Hall, D. R., \& Farman, D. I. (1998). Volatile constituents of the leaf and rhizome oils of Aframomum biauriculatum K. Schum. Journal of Essential Oil Research, 10(4), 447-449. https://doi.org/10 .1080/10412905.1998.9700940

Cimanga, K., Kambu, K., Tona, L., Apers, S., De Bruyne, T., Hermans, N., Totté, J., Pieters, L., \& Vlietinck, A. J. (2002). Correlation between chemical composition and antibacterial activity of essential oils of some aromatic medicinal plants growing in the Democratic Republic of Congo. Journal of Ethnopharmacology, 79(2), 213-220. https://doi. org/10.1016/s0378-8741(01)00384-1

Diomandé, G. D., Koffi, A. M., Tonzibo, Z. F., Bedi, G., \& Figueredo, G. (2012). $\mathrm{GC}$ and GC/MS analysis of essential oil of five Aframomum species from Côte D'ivoire. Middle-East Journal of Scientific Research, 11(6), 808-813.

Dongmo, S. C. M., Tamokou, J. D. D., Njateng, G. S. S., Pierre, T., \& JulesRoger, K. (2019). Chemical composition and antimicrobial activity of essential oils from Aframomum citratum, Aframomum daniellii, Piper capense and Monodora myristica. Journal of Medicinal Plants Research, 13(9), 173-187. https://doi.org/10.5897/jmpr2019.6768

Duke JA. (2002). CRC handbook of medicinal spices, CRC Press.

Edemhanria, Ebhomielen, \& Ebhohimen, I. E. (2020). Antioxidant effect of Aframomum angustifolium seed essential oil in freeze storage of lean meat. SAU Science-Tech Journal, 5(1), 97-103.

El-Halawany, A. M., Dine, R. S., Sayed, N. S., \& Hattori, M. (2014). Protective effect of Aframomum melegueta phenolics against $\mathrm{CCl} 4$-induced rat hepatocytes damage; Role of apoptosis and pro-inflammatory cytokines inhibition. Scientific Reports, 4. https://doi.org/10.1038/ srep05880

Emmanuel, P. D., Okerenta, B. M. O., \& Sarah, K. (2020). Essential oil compositions of Aframomum danielli Seed (Ataiko). Asian Journal of Research in Biochemistry, 30, 19-27. https://doi.org/10.9734/ ajrb/2020/v7i130130

Essien, E., Thomas, P., Oriakhi, K., \& Choudhary, M. (2017). Characterization and antioxidant activity of volatile constituents from different parts of Aframomum danielli (Hook) K. Schum. Medicines, 4(2), 29. https:// doi.org/10.3390/medicines4020029

Eyob, S., Appelgren, M., Rohloff, J., Tsegaye, A., \& Messele, G. (2008). Traditional medicinal uses and essential oil composition of leaves and rhizomes of korarima (Aframomum corrorima (Braun) P.C.M. Jansen) from southern Ethiopia. South African Journal of Botany,
74(2), 181-185. https://doi.org/10.1016/j.sajb.2007.10.007

Eyob, S, Martinsen, B. K., Tsegaye, A., Appelgren, M., \& Skrede, G. (2008). Antioxidant and antimicrobial activities of extract and essential oil of korarima (Aframomum corrorima (Braun) P.C.M. Jansen). African Journal of Biotechnology, 7(15), 2585-2592.

Eyob, S., Appelgren, M., Rohloff, J., Tsegaye, A., \& Messele, G. (2007). Chemical composition of essential oils from fresh plant parts of Korarima (Aframomum corrorima) cultivated in the highland of Southern Ethiopia. Journal of Essential Oil Research, 19(4). https:// doi.org/10.1080/10412905.2007.9699308

George B. O. (2011). Phenolic content and total antioxidant capacity of local spices in Nigeria. African Journal of Food Science, 5(13). https:// doi.org/10.5897/ajfs11.131

Hari, L., Bukuru, J., \& De Pooter, H. L. (1994). The volatile fraction of Aframomum sanguineum (K. Schum) H. Schum. from Burundi. Journal of Essential Oil Research, 6(4), 395-398. https://doi.org/10 1080/10412905.1994.9698405

Huong, L. T., Dai, D. N., Thang, T. D., Bach, T. T., \& Ogunwande, I. A. (2017). Analysis of the volatile constituents of Alpinia pinnanensis. Journal of Essential Oil-Bearing Plants, 20(1), 264-271. https://doi.org/10.10 80/0972060X.2017.1298474

Hymete, A., Rohloff, J., \& Iversen, T. H. (2006). Essential oil from seeds and husks of Aframomum corrorima from Ethiopia. Flavour and Fragrance Journal, 21(4), 642-644. https://doi.org/10.1002/ffj.1634

Inkoto C. L., Ngbolua K. T. N., Kilembe J. T., Ashande C. M., Lukoki F. L., Tshilanda D. D., Tshibangu D. S. T., \& Mpiana P. T., (2021). A mini review on the phytochemistry and pharmacology of Aframomum alboviolaceum (Zingiberaceae). South Asian Research Journal of Natural Products, 4(3), 24-35.

Koechlin, J. (1665). Lafore du Cameroun. V. 4, Scitaminales. Museum dHistoire Naturelle.

Jantan, I. B., Ahmad, F. B., \& Ahmad, A. S. (2004). Constituents of the rhizome and seed oils of greater galangal Alpinia galanga (L.) Willd. from Malaysia. Journal of Essential Oil Research, 16(3), 174-176. https://doi.org/10.1080/10412905.2004.9698687

Kress, JW., Prince, L. M., \& Williams, K. J. (2002). The phylogeny and a new classification of the gingers (Zingiberaceae): Evidence from molecular data. American Journal of Botany, 89(10), 1682-1696. https://doi.org/10.3732/ajb.89.10.1682

Kamtchouing, P., Mbongue, G., Dimo, T., Watcho, P., Jatsa, H., Sokeng, S. (2002). Effects of Aframomum melegueta and Piper guineenseon sexual behaviour of male rats. Behavioural Pharmacology, 13, 243-247.

Kamte, S. L. N., Ranjbarian, F., Campagnaro, G. D., Nya, P. C. B., Mbuntcha, H., Woguem, V., Womeni, H. M., Tapondjou, L. A., Giordani, C., Barboni, L., Benelli, G., Cappellacci, L., Hofer, A., Petrelli, R., \& Maggi, F. (2017). Trypanosoma brucei inhibition by essential oils from medicinal and aromatic plants traditionally used in Cameroon (Azadirachta indica, Aframomum melegueta, Aframomum daniellii, Clausena anisata, Dichrostachys cinerea and Echinops giganteus) International Journal of Environmental Research and Public Health, 14(7). https://doi.org/10.3390/ijerph14070737

Koga, A. Y., Beltrame, F. L., \& Pereira, A. V. (2016). Several aspects of Zingiber zerumbet: A review. Revista Brasileira de Farmacognosia, 26(3), 385-391. https://doi.org/10.1016/j.bjp.2016.01.006

Kuete, V., Krusche, B., Youns, M., Voukeng, I., Fankam, A. G., Tankeo, S., Lacmata, S., \& Efferth, T. (2011). Cytotoxicity of some Cameroonian spices and selected medicinal plant extracts. Journal of Ethnopharmacology, 134(3), 803-812. https://doi.org/10.1016/j. jep.2011.01.035

Kwazou, N. L., Dongmo, P. M. J., Ngoune, L. T., Sameza, M. L., Dongmo, B. N., Zollo, P. H. A., \& Menut, C. (2009). Propriétés antifongiques des huiles essentielles de quelques plantes du genre Aframomum du Cameroun contre Aspergillus flavus. Cameroon Journal of Experimental Biology, 5(1), 44-51. https://doi.org/10.4314/ cajeb.v5i1.44456

Lamaty, G., Menut, C., Koudou, J., Régnier, P., \& Bessière, J. M. (1993). Aromatic plants of tropical Central Africa. XI. Essential oils of leaf and seed of Aframomum melegueta (Roscoe) K. Schum. from Central African Republic. Journal of Essential Oil Research, 5(1), 81-83. https://doi.org/10.1080/10412905.1993.9698174

Lawal, B. A. S., Aderibigbe, A. O., Essiet, G. A., \& Essien, A. D. (2007). Hypotensive and antihypertensive effects of Aframomum melegueta seeds in humans. International Journal of Pharmacology, 3(4), 
311-318. https://doi.org/10.3923/ijp.2007.311.318

Lawal, O. A., Kasali, A. A., Opoku, A. R., Ojekale, A. B., Oladimeji, O. S., \& Bakare, S. (2015). Chemical composition and antibacterial activity of essential oil from the leaves of Aframomum melegueta (Roscoe) K. Schum from Nigeria. Journal of Essential Oil-Bearing Plants, 18(1), 222-229. https://doi.org/10.1080/0972060X.2014.960265

Lawal, O. A., Mosa, R. A., Opoku, A. R., \& Ogunwande, I. A. (2017). Essential oils of Aframomum danielli and Aframomum melegueta (Zingiberaceae): Chemical composition and antibacterial activity. American Journal of Essential Oils and Natural Products, 5(4), 14-19.

Martins, A., Salgueiro, L., Gonçalves, M., Cunha, A., Vila, R., Cañigueral, S., Mazzoni, V., Tomi, F., \& Casanova, J. (2001). Essential oil composition and antimicrobial activity of three Zingiberaceae from S.Tomé e Príncipe. Planta Medica, 67(6). https://doi.org/10.1055/s-2001-16494

Meffo, S. C. D., Njateng, G. S. S., Tamokou, J. D. D., Tane, P., \& Kuiate, J. R. (2019). Essential oils from seeds of Aframomum citratum (C. Pereira) K. Schum, Aframomum daniellii (Hook. F.) K. Schum, Piper capense (Lin. F) and Monodora myristica (Gaertn.) Dunal NL and their antioxidant capacity in a cosmetic cream. Journal of Essential Oil Bearing Plants, 22(2), 324-334. https://doi.org/10.1080/097206 Ox.2019.1612282

Menut, C., Lamaty, G., Zollo, P. H. A., Atogho, B. M., Abondo, R., \& Bessière, J. M. (1991). Aromatic plants of tropical central Africa. V. volatile components of three Zingiberaceae from Cameroon: Aframomum melegueta (Roscoe) K. Schum., A. daniellii (hook. f.) K. Schum. and A. Sulcatum (Oliv. and Hanb.) K. Schum. Flavour and Fragrance Journal, 6(3), 183-186. https://doi.org/10.1002/ ffj. 2730060304

Menut, C., \& Lamaty, G. (1991). Aromatic plants of Tropical Central Africa. V. volatile components of three Zingiberaceae from Cameroon: Aframomum melegueta (Roscoe) K. Schum., A. daniellii (Hook. f.) K. Schum. and A. sulcatum (O h. and Hanb.) K. Schum. Flavour and Fragrance Journal, 6, 183-186. https://doi.org/10.1002/ ffj.2730060304

Menut, C., Lamaty, G., Zollo, P. H. A., Abondo, R., \& Bessiére, J. M. (1994). Aromatic plants of tropical Central Africa. XII. Fruit essential oil of Aframomum pruinosum Gagnepain. A potential source of (E)-(R)nerolidol. Journal of Essential Oil Research, 6(1), 13-16. https://doi. org/10.1080/10412905.1994.9698317

Muriel, K. A., Tonzibo, Z. F., Koua, K. O., Bedi, G., \& Chalchat, J. C. (2011). Essential oil of Aframomum exscapum (sims) hepper from côte d'ivoire. Journal of Essential Oil-Bearing Plants, 14(3), 274-277. https://doi.org/10.1080/0972060X.2011.10643933

Ngakegni, L. A. C., Zebib, B., Cerny, M., Tsiba, G., Ndinga, A. M. E., Mouloungui, Z., Fourastier, I., \& Ouamba, J. M. (2013). Aframomum stipulatum (Gagnep) K. Schum and Aframomum giganteum (Oliv. \& Hanb) K. Schum as aroma tincto oleo crops resources: Essential oil, fatty acids, sterols, tocopherols, and tocotrienols composition of different fruit parts of congo varieties. Journal of the Science of Food and Agriculture, 93(1), 67-75. https://doi.org/10.1002/jsfa.5732

Ngbolua, K. N., Mihigo, S. O., Liyongo, C. I., Ashande, M. C., Tshibangu, D. S. T., Zoawe, B. G., Baholy, R., Fatiany, P. R., \& Mpiana, P. T. (2016). Ethno-botanical survey of plant species used in traditional medicine in Kinshasa city (Democratic Republic of the Congo). Tropical Plant Research, 3(2), 413-427.

Nguenang, G. S., Mbaveng, A. T., Fankam, A. G., Manekeng, H. T., Nayim, P., Wamba, B. E. N., \& Kuete, V. (2018). Tristemma hirtum and five other Cameroonian edible plants with weak or no antibacterial effects modulate the activities of antibiotics against Gram-negative multidrug-resistant Phenotypes. The Scientific World Journal, 7651482. https://doi.org/10.1155/2018/7651482

Nguikwie, S. K., Nyegue, M. A., Belinga, F. N. F., Ngono Ngane, R. A., Romestand, B., Kouzayha, A., Casabianca, H., Amvam Z. P. H., \& Menut, C. (2013). The chemical composition and antibacterial activities of the essential oils from three Aframomum species from Cameroon, and their potential as sources of (E)-(R)-nerolidol. Natural Product Communications, 8(6), 829-834. https://doi. org/10.1177/1934578x1300800638

Noumi, E., Snoussi, M., Alreshidi, M. M., Rekha, P. D., Saptami, K., Caputo, L., De Martino, L., Souza, L. F., Msaada, K., Mancini, E., Flamini, G., Al-Sieni, A., \& De Feo, V. (2018). Chemical and biological evaluation of essential oils from cardamom species. Molecules, 23(11). https://doi.org/10.3390/molecules23112818

Nyegue, M. A., Ndoye-Foe, F., Etoa, F. X., Zollo, P. H. A., \& Menut, C. (2014). Study of Chemical composition, growth inhibition and antigerminative effect of three essential oils from Cameroon on four Bacillus strains. Journal of Essential Oil-Bearing Plants, 17(6), 1335-1342. https://doi. org/10.1080/0972060X.2014.901608

Okpekon, T., Yolou, S., Gleye, C., Roblot, F., Loiseau, P., Bories, C., Grellier, P., Frappier, F., Laurens, A., \& Hocquemiller, R. (2004) Antiparasitic activities of medicinal plants used in Ivory Coast. Journal of Ethnopharmacology, 90(1), 91-97. https://doi.org/10.1016/j. jep.2003.09.029

Olagoke O. O., \& Amusat, M. (2019). GC/MS Analysis and evaluation of antimicrobial performance of Aframomum latifolium leaf essential oil from South West Nigeria. International Journal of Trend in Scientific Research and Development, 4(1), 189-191.

Olosunde, O. O., Adegoke, G. O., \& Abiodun, O. A. (2015). Composition of sorghum-millet flour, Aframomum danielli essential oil and their effect on mycotoxins in kunu zaki. African Journal of Food Science, 9(7), 411-416. https://doi.org/10.5897/ajfs2015.1319

Owokotomo, I. (2014). Chemical constituents of the leaf, stem, root and seed essential oils of Aframomum melegueta (K. Schum) from South West Nigeria. International Research Journal of Pure and Applied Chemistry, 4(4), 395-401. https://doi.org/10.9734/irjpac/2014/7397

Owokotomo, I. A. (2018). Bactericidal and brine shrimps toxicity of essential oils from Aframomum melegueta [K. Schum]. African Journal of Microbiology Research, 12(18), 419-425. https://doi.org/10.5897/ ajmr2017.8735

Owokotomo, I. A., Ekundayo, O., Abayomi, T. G., \& Chukwuka, A. V. (2015). In-vitro anti-cholinesterase activity of essential oil from four tropical medicinal plants. Toxicology Reports, 2, 850-857. https://doi. org/10.1016/j.toxrep.2015.05.003

Owolabi, M. S., Moronkola, A., Lajide, L., Palazzo, M. C., \& Setzer, W. N. (2010). Chemical composition of the seed volatiles of Aframomum sceptrum (oliv. \& t. hanb.) k. schum. from Nigeria. Journal of Essential Oil-Bearing Plants, 13(6), 753-758. https://doi.org/10.1080/097206 OX.2010.10643891

Pavela, R., Maggi, F., Mbuntcha, H., Woguem, V., Fogang, H. P. D., Womeni, H. M., Tapondjou, L. A., Barboni, L., Nicoletti, M., Canale, A., \& Benelli, G. (2016). Traditional herbal remedies and dietary spices from Cameroon as novel sources of larvicides against filariasis mosquitoes? Parasitology Research, 115(12), 4617-4626. https:// doi.org/10.1007/s00436-016-5254-4

Rana, V. S., Verdeguer, M., \& Blazquez, M. A. (2010). GC and GC/MS Analysis of the volatile constituents of the oils of Alpinia galanga (L.) Willd and A. officinarum Hance Rhizomes. Journal of Essential Oil Research, 22(6), 521-524. https://doi.org/10.1080/10412905.2010.9700388

Stuart, K., Brun, R., Croft, S., Fairlamb, A., Gürtler, R. E., McKerrow, J., Reed, S., \& Tarleton, R. (2008). Kinetoplastids: related protozoan pathogens, different diseases. Journal of Clinical Investigation, 118(4), 1301-1310. https://doi.org/10.1172/JCl33945

Tane, P., Tatsimo, S. D., Ayimele, G. A., \& Connolly, J. D. (2005). Bioactive metabolites from Aframomum species. $11^{\text {th }}$ NAPRECA Symposium Book of Proceedings, Antananarivo, Madagascar, 214-223

Telefo, P. B., Lienou, L. L., Yemele, M. D., Lemfack, M. C., Mouokeu, C., Goka, C. S., Tagne, S. R., \& Moundipa, F. P. (2011). Ethnopharmacologica survey of plants used for the treatment of female infertility in Baham, Cameroon. Journal of Ethnopharmacology, 136(1), 178-187. https:// doi.org/10.1016/j.jep.2011.04.036

Tia EV, Adima AA, Niamkéa SL, Jean GA, Martin T, Lozano P, \& Menut C. (2011). Chemical composition and insecticidal activity of essential oils of two aromatic plants from Ivory Coast against Bemisia tabaci G. (Hemiptera: Aleyrodidae). Natural Product Communications, 6(8), 1183-1188.

Titanji, V. P. K., Zofou, D., \& Ngemenya, M. N. T. (2008). The antimalarial potential of medicinal plants used for the treatment of malaria in Cameroonian folk medicine. African Journal of Traditional, Complementary and Alternative Medicines, 5(3), 302-321.

Ukeh, D. A. (2008). Bioactivities of essential oils of Aframomum melegueta and Zingiber officinale both (Zingiberaceae) against Rhyzopertha dominica. Journal of Entomology, 5(3), 193-199.

Zahara, M., Hasanah, M., \& Zalianda, R. (2018). Identification of Zingiberaceae as medicinal plants in Gunung Cut Village, Aceh Barat Daya, Indonesia. Journal of Tropical Horticulture, 1(1), 24-28. https:// doi.org/10.33089/jthort.v1i1.9

Zakir M. (2018). Review on Korarima (Aframomum corrorima (Braun) P.C.M. Jansen) Research Achievements, Challenges and Future Prospective in Ethiopia. International Journal of Research Studies in Agricultural Sciences, 4(1), 29-36. 